\title{
Germinoma of the Medulla Oblongata
}

\section{-Case Report-}

\author{
Kazuhiko SugiYama, Tohru UOzUMI, Junji Golshi*, Takashi SOGABE*, \\ Kazunori ARITA, Hitoshi MAEDA, and Fusao IKAWA
}

\author{
Department of Neurosurgery, Hiroshima University School of Medicine, Hiroshima; \\ *Department of Neurosurgery, Matsuyama Red Cross Hospital, Matsuyama
}

\begin{abstract}
A 32-year-old female presented with medulla oblongata germinoma manifesting as numbness in the extremities. Computed tomography demonstrated a mass in the medulla oblongata expanding into the fourth ventricle. The tumor was partially removed. Immunohistochemical staining of the tumor specimen demonstrated large epithelioid cells positive for placental alkaline phosphatase, and syncytiotrophoblastic cells positive for $\beta$ subunit of human chorionic gonadotropin. Some epithelioid cells were also positive for cytokeratin. She received $44 \mathrm{~Gy}$ of irradiation to the posterior fossa and 20 Gy whole spinal irradiation. No signs of recurrence have occurred for 9 years. Patients with medulla oblongata germ cell tumor are comparatively older than those with other intracranial germ cell tumors and have two $\mathrm{X}$ chromosomes. All tumors were diagnosed as germinoma, and caused symptoms of involvement of the lower cranial nerves and the lower brain stem without pyramidal tract signs.
\end{abstract}

Key words: cytokeratin, germinoma, medulla oblongata, syncytiotrophoblastic giant cells

\section{Introduction}

Intracranial germ cell tumor (GCT) usually develops in the pineal or hypothalamic and neurohypophyseal regions, ${ }^{1,4,5,12,14)}$ only occurring elsewhere in $2-3 \%$ of cases. $^{5,12,13)}$ Locations include the cerebral hemisphere, ${ }^{(0,17)}$ spinal cord, ${ }^{2,8)}$ septum pellucidum, ${ }^{7)}$ and cerebellar hemisphere, ${ }^{11,13,15,16)}$ and are both pathologically and embryologically unusual, providing the basis for many theories about the pathogenesis of intracranial GCTs. ${ }^{5,9,12\}}$

We describe a very rare case of medulla oblongata germinoma and discuss the characteristics of GCT in this site.

\section{Case Report}

A 32-year-old female visited our department complaining of numbness in all extremities, hoarseness, and unsteady gait on January 23, 1984. Her past medical history included an accident in 1970 with head trauma requiring enucleation of the left eye. In April, 1983, numbness developed in her right upper and lower extremities. Two months later, all four extremities were involved. Her symptoms slowly worsened, despite drug medication at a nearby clinic. She noted unsteady gait and a hoarse voice in carly January, 1984.

On admission, she was lucid. Growth of pubic hair was normal, and there was no history of polyuria and menstrual problems. Neurological examination found pareses of the left VIIth and the bilateral IXth, Xth, and XIIth cranial nerves, as well as trunkal ataxia. The extremities showed decreased touch and pain sensation. However, the extraocular movements and the pupillary reflex of the right eye were normal. Fundoscopic examination had no abnormalities. Postcontrast computed tomography (CT) revealed a high-density mass extending from the dorsal medulla oblongata to the fourth ventricle (Fig. 1). No abnormalities were seen in the pineal or the hypothalamic and neurohypophyseal regions.

Received May 17, 1993; Accepted November 2, 1993

Author's present address: K. Sugiyama, M.D., Division of Neuropathology, Department of Pathology, Montefiore Medical Center, Bronx, New York, U.S.A. 


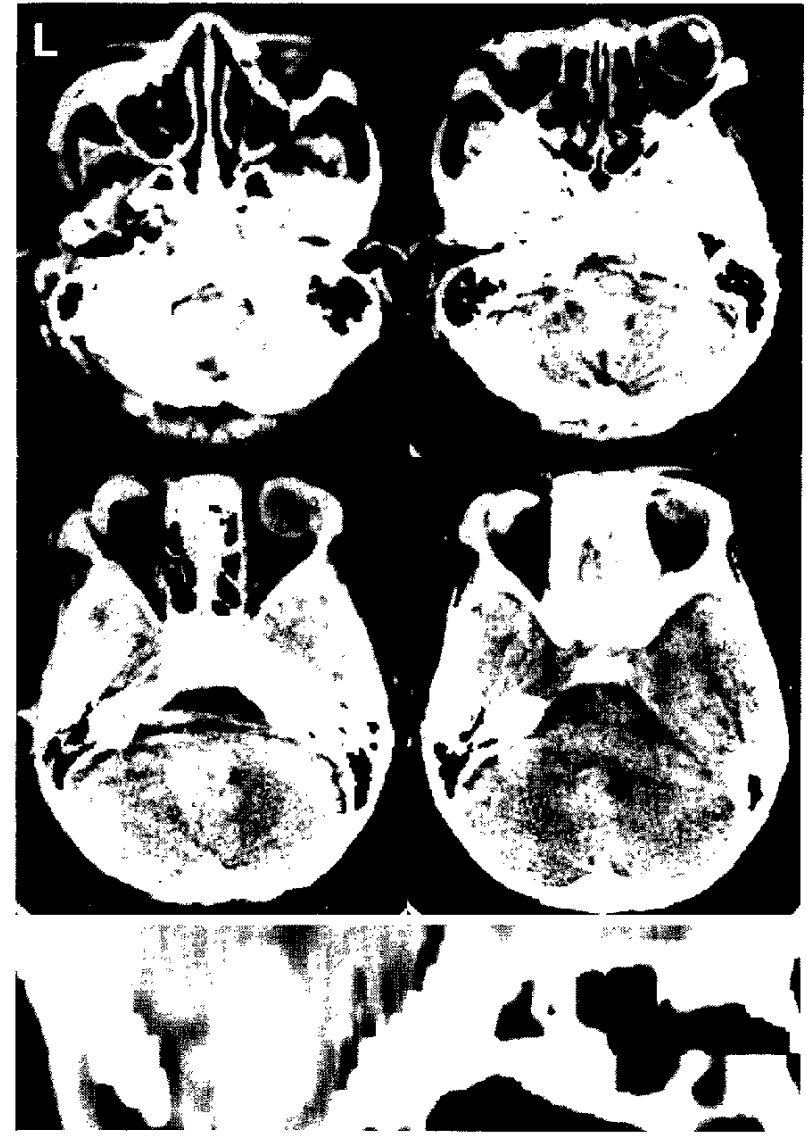

Fig. 1 upper: Postcontrast CT scans on admission, showing an enhanced tumor in the dorsal medulla oblongata and fourth ventricle. lower: Reconstructed CT scan, revealing the relationship between the tumor and the medulla oblongata more clearly.

On February 10, the tumor was partially removed via a midline suboccipital approach. The tumor was located in the cisterna magna, compressing the vermis upward. After removing part of the vermis, the tumor was removed. However, the part of the tumor firmly fixed to the medulla could not be removed.

Surgical specimens were immediately fixed in $10 \%$ buffered formalin solution, embedded in paraffin, and sectioned into $6-\mu \mathrm{m}$ thick slices. Deparaffinized specimens were stained with the streptoavidin-biotincomplex method using mouse monoclonal antibodies against placental alkaline phosphatase (PLAP), $\beta$ subunit of human chorionic gonadotropin (HCG- $\beta$ ), $\alpha$-fetoprotein (AFP), cytokeratin, vimentin, and epithelial membrane antigen (EMA). Proteolyses was performed with $0.1 \%$ trypsin solution before cytokeratin immunohistochemical staining. The tumor contained two types of cells. The first, more numerous type was large, polygonal, or spheroidal, with eosinophilic and vacuolated cytoplasm, and large nuclei often containing large nucleoli. The second type was lymphocytic (Fig. 2A). The large cells were immunoreactive for PLAP (Fig. 2B). The tumor also contained multinucleated syncytiotrophoblastic giant cells (STGCs) immunoreactive for HCG- $\beta$ (Fig, 2C). In contrast, some large epithelioid cells contained cytokeratin (Fig. 2D). The tumor cells were not immunoreactive for AFP, vimentin, and EMA. The tumor histological diagnosis was germinoma with STGC.

Postoperatively, she received 44 Gy of external beam irradiation to the posterior fossa, and $20 \mathrm{~Gy}$ to the whole spinal cord. After the posterior fossa irradiation, CT of the brain showed that the residual tumors had disappeared (Fig. 3). She was discharged with only slight hoarseness and dysphagia on May 8. Nine years later, she has suffered no tumor recurrence and is working normally as a housewife.

\section{Discussion}

Our diagnosis of germinoma primarily involving the medulla oblongata was based on the CT and intraoperative findings, the absence of the characteristic symptoms of GCT in the pineal or hypothalamic and neurohypophyseal regions, $1,4.5,11,14)$ and no recurrence for 9 years after irradiation to the posterior fossa and the spinal cord, without supratentorial irradiation or chemotherapy. ${ }^{181}$

GCT occurring in the medulla oblongata is very rare, with three previously reported cases in Japan $^{3,11,18\rangle}$ (Table 1). All patients had two $X$ chromosomes: one patient was "male" with Klinefelter syndrome, and three were female. All patients were comparatively older than those with other intracranial GCTs. ${ }^{512)}$ All tumors were histologically diagnosed as germinoma, located on the dorsal medulla oblongata and extending into the fourth ventricle and the cisterna magna, compressing the vermis in a caudorostral direction. Clinical manifestations included involvement of the lower cranial nerves and dysfunctions of the lower brainstem and cerebellum without pyramidal tract signs.

Our case demonstrated some epithelioid cells immunoreactive for cytokeratin. Nakagawa et $a l^{91}$ showed that three of 11 germinomas were immunoreactive for cytokeratin, two of which originated in the posterior fossa. GCT occurring in the posterior fossa usually develops in the cerebellar hemispheres. ${ }^{6,13,15,16,191}$ Most cerebellar GCT types demonstrate AFP production, such as endodermal sinus tumor and embryonal carcinoma, and are im- 


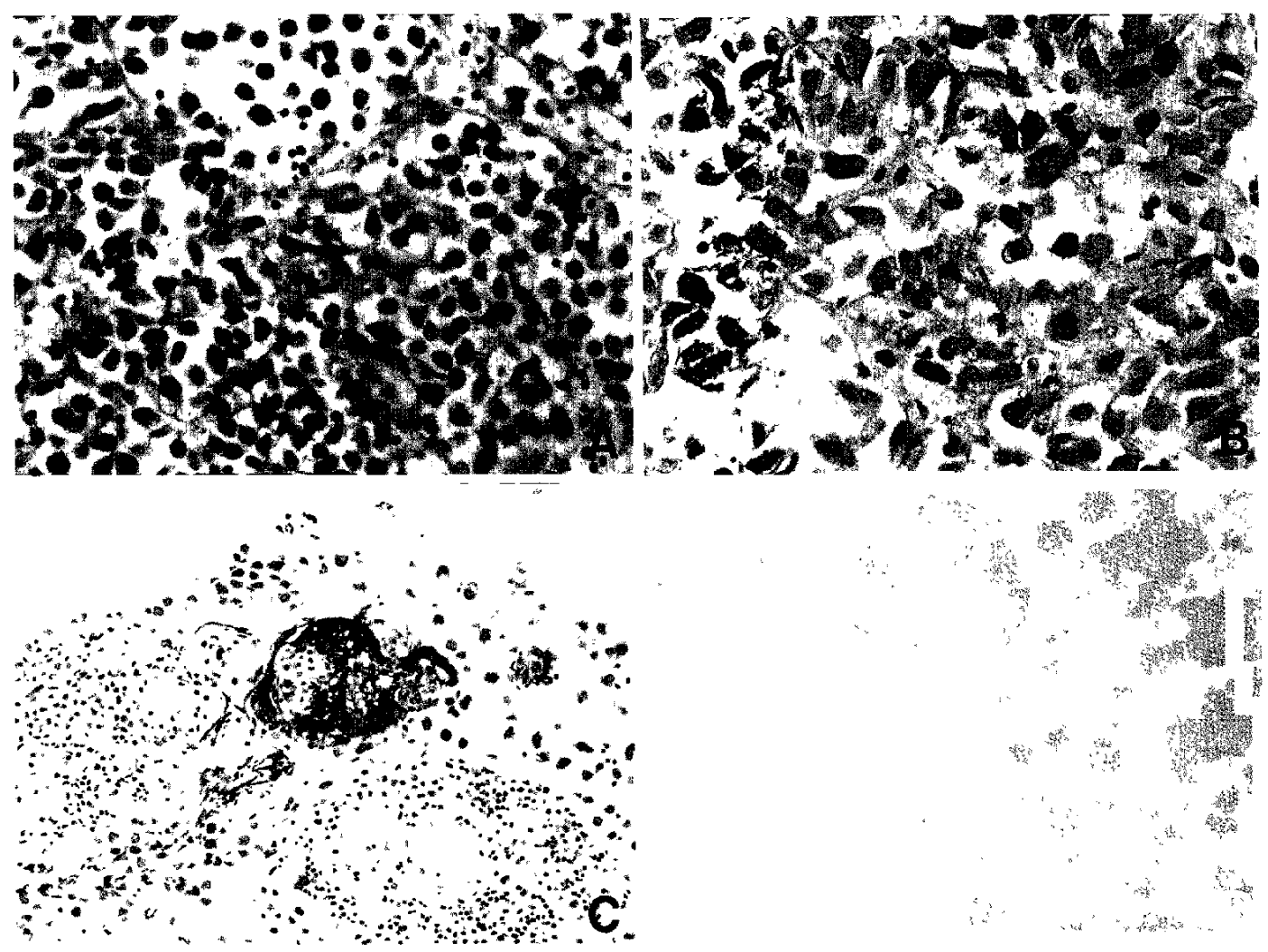

Fig. 2 Photomicrograph, demonstrating both large epithelioid cells and lymphocytes with vascularized connective tissue (A: hematoxylin and eosin stain, $\times 160$ ). Photomicrographs of immunohistochemical staining, showing the cell membrane and cytoplasm immunoreactive for PLAP (B: PLAP immunostain, $\times 160$ ), STGCs immunoreactive for $\mathrm{HCG}-\beta$ (C: HCG- $\beta$ immunostain, $\times 80$ ), and epithelioid cells immunoreactive for cytokeratin (D: cytokeratin immunostain, $\times 320$ ).

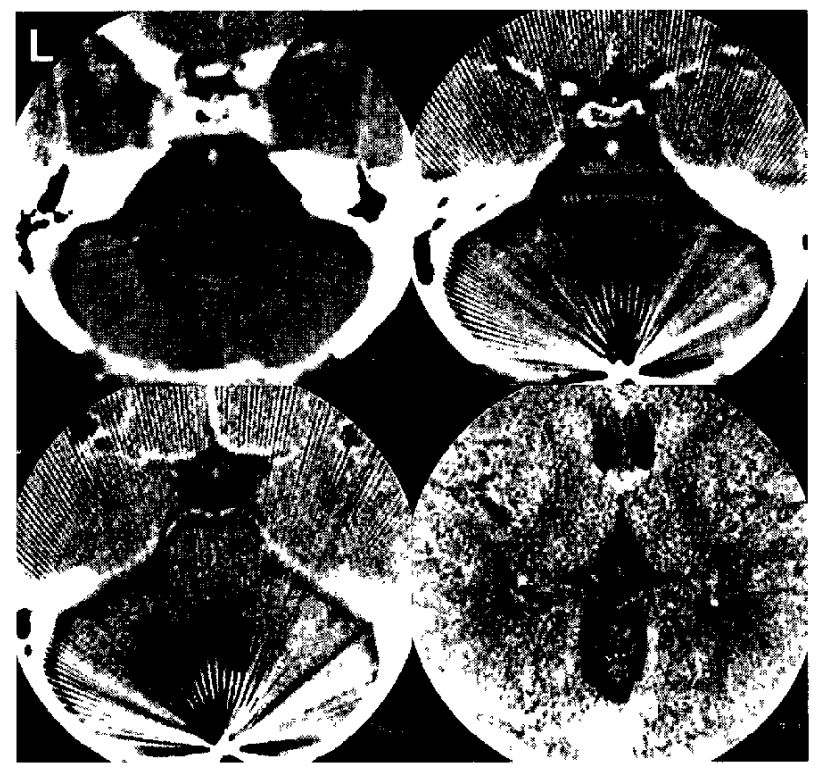

munoreactive for cytokeratin." The presence or absence of cytokeratin in a germinoma may be related to its site of origin within the central nervous system. ${ }^{1,121}$

\section{References}

1) Burger PC, Sheithauer BW, Vogel FS: Surgical Pathology of the Nervous System and its Coverings, ed 3. New York, Churchill Livingstone, 1991, pp 386-398

2) Garrison JE, Kasdon DL: Intramedullary spinal teratoma. Neurosurgery 7: 509-512, 1980

3) Hashimoto $M$, Hatasa $M$, Shinoda $S$, Masuzawa $T$ :

Fig. 3 Postcontrast CT scans after posterior fossa irradiation, demonstrating the disappearance of the residual tumor and absence of tumors in the pineal and neurohypophyseal regions. 
Table 1 Clinical features of reported cases of germ cell tumor in the medulla oblongata

\begin{tabular}{|c|c|c|c|c|c|}
\hline Author (Year) & $\begin{array}{c}\text { Age } / \\
\text { Sex }\end{array}$ & Symptoms & Treatment & Histology & Outcome \\
\hline $\begin{array}{l}\text { Saito et al. } \\
\qquad(1983)^{11}\end{array}$ & $14 / F$ & $\begin{array}{l}\text { headache, vertigo, } \\
\text { hoarseness, } \\
\text { swallowing difficulty }\end{array}$ & $\begin{array}{l}\text { total removal, } \\
\text { irradiation }\end{array}$ & germinoma & $\begin{array}{l}\text { died at } 2 \text { mos } \\
\quad(G-I \text { bleeding })\end{array}$ \\
\hline$\underset{(1992)^{3)}}{\text { Hashimoto et al. }}$ & $19 / \mathrm{M}^{*}$ & $\begin{array}{l}\text { swallowing difficulty, } \\
\text { sleep apnea }\end{array}$ & $\begin{array}{l}\text { biopsy, } \\
\text { irradiation ( } 60 \mathrm{~Gy})\end{array}$ & germinoma & $\begin{array}{l}\text { alive at } 2 \text { mos } \\
\text { with no relapse }\end{array}$ \\
\hline $\begin{array}{l}\text { Tashiro et al. } \\
\quad(1993)^{181}\end{array}$ & $30 / \mathrm{F}$ & $\begin{array}{l}\text { numbness of extremities, } \\
\text { gait disturbance, } \\
\text { swallowing difficulty }\end{array}$ & $\begin{array}{l}\text { biopsy, } \\
\text { chemotherapy }(P+E)\end{array}$ & $\begin{array}{l}\text { germinoma } \\
\text { (elevated } \\
\text { serum HCG) }\end{array}$ & $\begin{array}{l}\text { relapse at } 6 \mathrm{mos} \\
\text { alive at } 8 \mathrm{mos}\end{array}$ \\
\hline Present case & $32 / \mathrm{F}$ & $\begin{array}{l}\text { numbness of extremities, } \\
\text { unsteady gait, } \\
\text { hoarseness }\end{array}$ & $\begin{array}{l}\text { partial removal, } \\
\text { irradiation ( } 44 \mathrm{~Gy})\end{array}$ & $\begin{array}{l}\text { germinoma with } \\
\text { STGC }\end{array}$ & $\begin{array}{l}\text { alive at } 9 \text { yrs } \\
\text { with no relapse }\end{array}$ \\
\hline
\end{tabular}

${ }^{*}$ Klinefelter syndrome. G-I: gastrointestinal, P + E: cis-diaminedichloroplatinum and etoposide.

Medulla oblongata germinoma in association with Klinefelter syndrome. Surg Neurol 37: 384-387, 1992

4) Hoffman $\mathrm{HJ}$, Otsubo $\mathrm{H}$, Hendrick EB, Humphreys RP, Drake JM, Becker LE, Greenberg M, Jenkin D: Intracranial germ-cell tumors in children. $J$ Neurosurg 74: 545-551, 1991

5) Jennings MT, Gelman R, Hochberg F: Intracranial germ-cell tumors: Natural history and pathogenesis. $J$ Neurosurg 63: 155-167, 1985

6) Khantanaphar S, Bunyaratvej S: Embryonal carcinoma in the cerebellum. Case report. $J$ Neurosurg 40: $657-662,1974$

7) Koyama S, Tsubokawa T, Katayama $Y$, Hirota $H$ : Choriocarcinoma of the septum pellucidum: Case report. Surg Neurol 35: 478-482, 1992

8) Matsuoka $\mathrm{S}$, Itoh $\mathrm{M}$, Shinonome $\mathrm{T}$, Tanimura $\mathrm{A}$ : Intramedullary spinal germinoma: Case report. Surg Neurol 35: 122-126, 1992

9) Nakagawa Y, Perentes E, Ross GW, Ross AN, Rubinstein LJ: Immunohistochemical differences between intracranial germinomas and their gonadal equivalents. An immunoperoxidase study of germ cell tumors with epithelial membrane antigen, cytokeratin and vimentin. $J$ Pathol 156:67-72, 1988

10) Okuno $S$, Hisanaga $M$, Miyasaki A, Tsunoda $S$, Sakaki T: A case of intracranial germinoma responsive to amphotericin B. Gan To Kagaku Ryoho 19: 373-377, 1992 (in Japanese)

11) Saito A, Yamashita $T$, lshiwata $Y$, Hirata $K$, Kuwabara T: A case of germinoma of the fourth ventricle. Shoni No Noshinkei 8: 43-48, 1983 (in Japanese)

12) Sano K, Matsutani M, Seto $T$ : So called intracranial germ cell tumors: Personal experiences and a theory of their pathogenesis. Neurol Res 11: 118-126, 1989

13) Strang RR, Tovi D, Schisano G: Teratoma of the posterior cranial fossa. Zbl Neurochir 20: 357-373, 1960

14) Sugiyama K, Uozumi T, Kiya K, Mukada K, Arita K, Kurisu K, Hotta T, Ogasawara H, Sumida M: Intracranial germ-cell tumor with synchronous lesions in the pineal and suprasellar regions: Report of six cases and review of the literature. Surg Neurol 38: 114-120, 1992

15) Tajika T, Aoki N, Mizutani H, Mizuguchi K, Kubo $\mathrm{O}$ : Pediatric endodermal sinus tumor: Case report. Shoni No Noshinkei 13: 225-228, 1988 (in Japanese)

16) Takeda $Z$, Maeda $H$, Itoh $H$, Shirataki K, Kobayashi N, Sakamoto K: Yolk sac tumor in the cerebellum. A case report. Kobe $J$ Med Sci 31: 63-72, 1985

17) Tanaka $\mathbf{R}$, Ueki $\mathbf{K}$ : Germinoma in the cerebral hemisphere. Surg Neurol 12: 239-241, 1979

18) Tashiro T, Yoshida J, Wakabayashi T, Sugita K, Abe $\mathrm{H}$ : Primary intracranial germinoma involving the medulla oblongata: Case report. Neurol Med Chir (Tokyo) 33: 251-254, 1993

19) Tsukamoto H, Matsushima $T$, Shono S, Miyazono M, Fukui M, Kondo A: Primary yolk sac tumor of the cerebellar vermis. Surg Neurol 38: 50-56, 1992

Address reprint requests to: K. Sugiyama, M.D., Department of Neurosurgery, Hiroshima University School of Medicine, 1-2-3 Kasumi, Minami-ku, Hiroshima 734, Japan. 